\begin{tabular}{|c|c|c|}
\hline PORT SAID ENGINEERING RESEARCH JOURNAL \\
Faculty of Engineering - Port Said University \\
Volume 16 No.1 pp: 137:149
\end{tabular}

\title{
Environmental Assessments For Areas Located Both Sides of Bahr El-Baqar Polluted Drain Northeastern Egypt
}

\author{
Salem, $\mathrm{Sh}^{1}$, Hamed, $Y^{2}$,Sheshtawy, $A^{3}$, and Ali, $A^{4}$
}

\section{ABSTRACT}

This template is set up to allow printing on A4 paper. For optimum use, do not make changes or modifications to the page layout or paragraph styles. The information given here is generally applicable, but individual journals may have their own specific requirements. Finally, the journal title should be appeared in the first page only. Bahr El-Baqar drain in northeastern Egypt is considered as one of the most polluted drains in Egypt. The use of polluted water from the drain in fish farms and agricultural lands has a very dangerous environmental effect on soil and ground water. Besides, seepage from the polluted drain to the adjacent lands has a great effect on the quality of the ground water in the area. The main objective of the current research is to conduct an integrated environmental assessment for areas located both sides of Bahr El- Baqar drain for the last $20 \mathrm{~km}$ length of the drain before it charges its water into Manzala Lake. In order to achieve that, the effects of using polluted drain water in new/old fish farms and agricultural lands were investigated. Pollution level in moor and fill lands adjacent to the drain were also investigated. In addition, effect of seepage from the polluted drain to the adjacent lands has been studied. Water and soil samples have been collected and analyzed in order to calculate the concentrations of five main heavy metals $(\mathrm{Pb}, \mathrm{Zn}, \mathrm{Cd}$, $\mathrm{Cu}$ and $\mathrm{Mn}$ ). Samples were collected from different depths ranging from $0.5 \mathrm{~m}$ to $4 \mathrm{~m}$ in 24 different locations for the study area. Different locations have been chosen in new/old fish farms, lands adjacent to the fish farms, moor lands, fill lands and agricultural lands using polluted drain water and fresh water from the canal.

Results showed that the areas of old fish farms have received the highest concentration ratios in heavy metals. Results also showed that the fish farms using polluted water have not only dangerous effect on its own soil but also has almost the same bad effect on the adjacent areas surrounding it. The next highest ratios were found in agricultural lands using polluted water for irrigation. Furthermore, Results showed that the effect of using polluted water for irrigation or raising fish is more dangerous than the effect of seepage from the polluted drain.

\section{INTRODUCTION}

One of the most dangerous hazards affecting the environment situation in arid and semi-arid countries like Egypt is the water and soil pollution. Due to the lack of fresh water for irrigation, countries in arid and semi arid areas are forced to use marginal waters for irrigation. The effect of using such kind of low quality water in irrigation is rather dangerous on the environmental situation. Besides, countries like Egypt are facing great problems to get rid of untreated waste water and industrial disposal in addition to drainage

${ }^{1}$ Civil Engineer at Ministry of Water recourses and irrigation.

2 Assoc. Prof, Civil Engineering Department, Faculty of Engineering, Suez Canal University, Port Said, Egypt.

3 Doctor, Civil Engineering Department, Faculty of Engineering, Suez Canal University, Port Said, Egypt.

${ }^{4}$ Prof, Irrigation and Hydraulics Department, Faculty of Engineering, Ain Shams University, Egypt. will cause great problems to the eco-system and environment in general. What will make the problem more complicated is the use of these waters for irrigation or raising fish due to lack of fresh waters.

Bahr El-Baqar drain is considered one of the most polluted drains in Egypt (Abdel-Shafy \& Aly 2002)[1]. It receives and carries the greatest part of wastewater (about 3 BCM/year) into Lake Manzala through a very densely populated area of the Eastern Delta passing through four highly populated Governorates. Bahr El-Baqar drain has received treated sewage, Industrial Wastewater both treated and raw and Land drainage of a cultivated area which load the drain water with the heavy metals. Unfortunately, at the last decades, great areas on both sides of the drain were using its polluted water for irrigation and raising fish. As a polluted drain with high risk to the surrounding environment, Bahr El-Baqar has received considerable concern by many scientists. Ali et al. (1993), Abdel-Azeem et al. (2007)[2],[3] studied the effect of prolonged use of drain water for irrigation on the total heavy metals content of south Port-Said city soils. They found that using such 
kind of water will cause high concentration of heavy metals in soil and plants roots and shots. Water quality, chemical composition, and hazardous effects on Lake Manzala water and living organisms caused by Bahr El-Baqar drain water has also been studied by several investigators like: Rashed and Holmes (1984), Khalil (1985) and Ezzat (1989)[4],[5],[6]. Special attention has been paid to the effect of environmental pollution from microbiological and toxicological points of view (Zaki 1994 )[7].

Hamed 2008[8], studied the effect of fish farms on both of soil structure and salinity in area near the study area of the current research and with the same type of soil. He found that fish farming does not contribute to decrease in the soil salinity. He concluded that increasing fish farming activities may lead to increasing soil salinity problems in agricultural lands. The results showed also that there is no evidence that soil properties are enhanced by fish farming. On the contrary, the soil nutrient state appears to be decreasing.

Bahr El-Baqar drain spills more than $3 \mathrm{BCM} /$ year into Lake Manzala, the largest of Egypt's Mediterranean wetlands, and the most productive for fisheries. As a result, the lake is suffering from industrial and nutrient pollution and overgrowth by water hyacinth. The spatial changes in average salinity of lake Manzala show also a declining trend from the northern sector to the southern one, as detected from five stations and reported by Khalil (1990). Station I in the northern sector is the most saline part $(>30,000 \mathrm{mg} / \mathrm{l})$. However, station II, in the middle, is brackish $(15,000$ $25,000 \mathrm{mg} / \mathrm{l})$. Station III is transitional $(3,000-15,000 \mathrm{mg} / \mathrm{l})$. Station IV is slightly brackish $(2,000-5,000 \mathrm{mg} / \mathrm{l})$ and finally, station $\mathrm{V}$ in the southern sector is of the lowest salinity $(<2,000 \mathrm{mg} / \mathrm{l})$ in Bahr El-Baqar Drain (Khalil, 1990)[9].

A national project called El-Salam Canal has recently finished. It relies on mixing water from the Damietta Branch of the Nile River with water from two major agricultural drains to be used for irrigation of 600,000 Feddan in the western side of Suez Canal and North Sinai. A total annual water requirement of 4.45 billion $\mathrm{m}^{3}$ of mixed water is required to irrigate 600,000 Feddan as follows:

- 2.11 billionm $^{3}$ fresh water from the Damietta branch, _ 0.435 billionm $^{3}$ drainage water from the Elserw drain,and

- 1.905 billionm $^{3}$ drainage water from the Bahr Hadous drain.

The 200000 Feddan located within the service area of ElSalam Canal in western part of Suez Canal charging their drainage water into Bahr El- Baqar drain. Some agricultural areas located near the drain use El-Salam Canal water for irrigation.

The objective of the proposed study is to conduct an integrated environmental assessment for area located adjacent to the most polluted drain in northeastern Egypt. The level of pollution in soil and water will be recorded as a result of using the polluted water from the drain for irrigation and raising fish. The problem of seepage from the drain will be investigated.

\section{METHODS AND MATERIALS}

\subsection{Area description}

The field experiments were conducted in year 2010 in area located at the last $20 \mathrm{~km}$ of the Bahr El- Baqar drain before it charges its water in Manzala Lake. The study area consists of agricultural lands, fish farms, lands adjacent to the fish farms, lands subjected to fill from the drain and moor lands. The area is located within the service area of the national project El-Salam Canal south of Port Said city.

Total of 24 boreholes were dug in 8 horizontal sections for different locations at the study area. Every horizontal section has length of 54-162 m from the Bahr El-Baqar drain side and contains three boreholes. Fig (1) shows the location of the horizontal sections while Fig (2) shows the locations of the boreholes.

Four sections were taken at each side of the drain. The depth of each borehole is 1.5-4 m. Five of the boreholes were conducted in new/old fish farms. Three boreholes were conducted near the old fish farms (near the border of the farms). Six boreholes were conducted in moor lands and seven boreholes in fill land adjacent to the drain. Three boreholes were conducted in agricultural lands; two of them in agricultural land using the polluted water and one in agricultural land using fresh canal water. The agricultural land using fresh canal water has used polluted water from the drain for irrigation for 25 years and changed to use fresh water from the canal 5 years ago. The soil type in the study area is silty clay soil with more than $60 \%$ clay. Boreholes taken in moor lands will be used for comparison.

\subsection{Soil/water samples}

Two soil samples were collected from each borehole. Hamed et al (2011) Collected water samples from the polluted drain at the same location of the study area for one year (one sample per month), one year before the study were conducted. Water samples were collected in sterile well stopper sterilized 1000-ml polyethylene bottles and transferred in an ice box to the laboratory. These results will be used in this study in order to study the yearly level of pollution in Bahr El-Baqar drain and compare the results to the level of pollution in soil adjacent to the drain. Chemical analyses were carried out within $24 \mathrm{hr}$ of sampling at the laboratory. The concentrations of five heavy metals $(\mathrm{Pb}, \mathrm{Zn}$, $\mathrm{Cu}, \mathrm{Mn}$, and $\mathrm{Cd}$ ) were analyzed for each soil sample. Heavy metals were analyzed by the total adsorbed metals method according to USEPA (1986)[10] using atomic spectrophotometer (model PYE UNICAM SP9, England).

The agricultural lands in the area are supposed to be irrigated with fresh water from El-Salam canal or its branches but due to water shortage especially in summer most of the lands use the drain water for irrigation or for raising fish. There is a drain called Sarhan drain or Port Said drain parallel to Bahr El-Baqar drain at the eastern side located $100 \mathrm{~m}$ far from the drain. It collects the drainage water from the area nearby and spills it again to Bahr ElBaqar drain.

\subsection{Experimental setup}

Boreholes were taken by rotary boring method at 8 sections, 4 sections at each side of Bahr El-Baqar drain. Every section contains three boreholes. Two soil samples 
and one water sample were taken from every borehole. One soil sample was taken above water table and the other taken under water table. The total depth of each borehole is $4 \mathrm{~m}$.

Table (1) shows locations and depths of boreholes. It shows also the type of land use of each borehole.
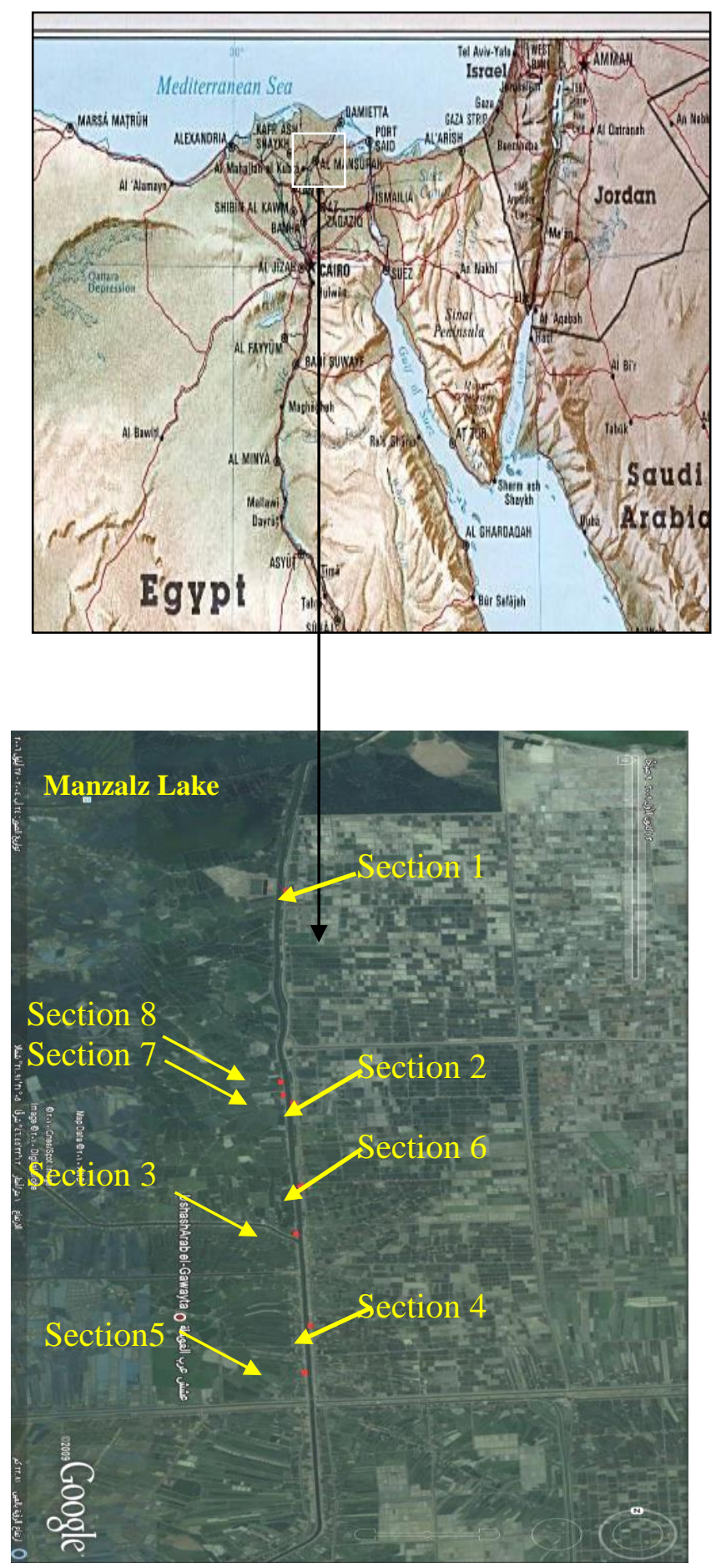

Fig (1) locations of the horizontal sections

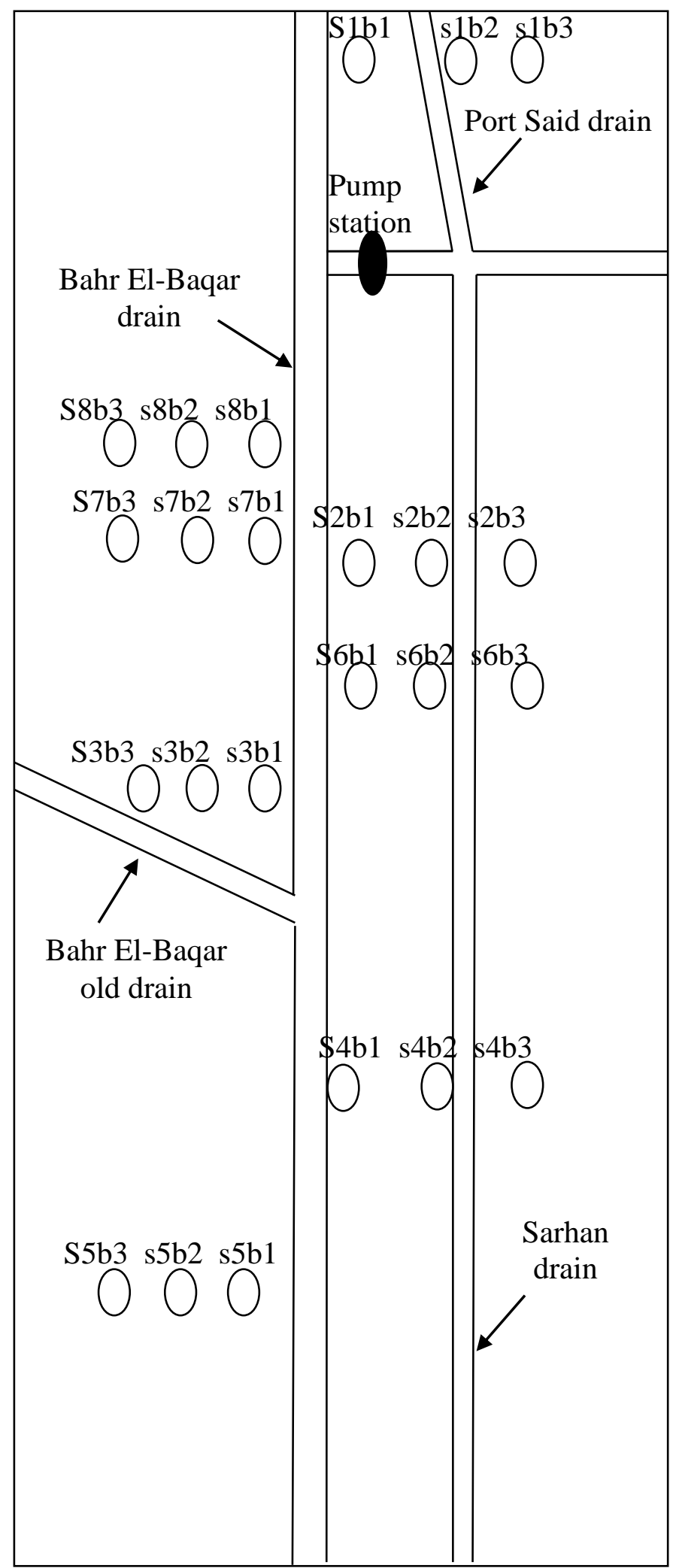

Fig (2) Layout of the boreholes 
Table (1) Locations and depths of boreholes and type of land use (U: upper layer. L: lower layer)

\begin{tabular}{|c|c|c|c|c|c|c|c|}
\hline Sector & Side & Bore hole & $\begin{array}{l}\text { Distance } \\
\text { From Bahr } \\
\text { El-Baqar } \\
\text { drain(m) }\end{array}$ & Symbol / no. & $\begin{array}{l}\text { Depth } \\
(\mathrm{m})\end{array}$ & Land use & $\begin{array}{l}\text { Water } \\
\text { table } \\
\text { depth } \\
\end{array}$ \\
\hline \multirow{6}{*}{ S1 } & \multirow{6}{*}{ right } & \multirow{2}{*}{ S1b1 } & \multirow{2}{*}{60} & S1b1U & 1.5 & \multirow{2}{*}{$\begin{array}{c}\text { Old Fish farm(10 } \\
\text { years old ) }\end{array}$} & \multirow{2}{*}{1.65} \\
\hline & & & & S1b1L & 4 & & \\
\hline & & \multirow{2}{*}{$\mathrm{S} 1 \mathrm{~b} 2$} & \multirow{2}{*}{142} & S1b2U & 1 & \multirow{2}{*}{$\begin{array}{l}\text { land adjacent to } \\
\text { old fish farm }\end{array}$} & \multirow{2}{*}{1.2} \\
\hline & & & & S1b2L & 3 & & \\
\hline & & \multirow[b]{2}{*}{ S1b3 } & \multirow[b]{2}{*}{162} & S1b3U & 1 & \multirow{2}{*}{$\begin{array}{c}\text { New Fish } \\
\text { farm(two years } \\
\text { old ) }\end{array}$} & \multirow[b]{2}{*}{1.3} \\
\hline & & & & S1b3L & 4 & & \\
\hline \multirow{6}{*}{ S2 } & \multirow{6}{*}{ right } & \multirow{2}{*}{$\mathrm{S} 2 \mathrm{~b} 1$} & \multirow{2}{*}{32.5} & S2b1U & 0.8 & \multirow{2}{*}{$\begin{array}{l}\text { Old Fish farm(10 } \\
\text { years old ) }\end{array}$} & \multirow{2}{*}{2.2} \\
\hline & & & & S2b1L & 2.5 & & \\
\hline & & \multirow{2}{*}{$\mathrm{S} 2 \mathrm{~b} 2$} & \multirow{2}{*}{65} & S2b2U & 0.7 & \multirow{2}{*}{$\begin{array}{c}\text { Old Fish farm (10 } \\
\text { years old ) }\end{array}$} & \multirow{2}{*}{2.5} \\
\hline & & & & S2b2L & 2.75 & & \\
\hline & & \multirow{2}{*}{ S2b3 } & \multirow{2}{*}{131} & S2b3U & 0.7 & \multirow{2}{*}{$\begin{array}{l}\text { Fill from Sarhan } \\
\text { drain }(5 \text { years old })\end{array}$} & \multirow{2}{*}{1.5} \\
\hline & & & & S2b3L & 2 & & \\
\hline \multirow{6}{*}{ S3 } & & & & S3b1U & 0.5 & Fill from Bahr El- & \\
\hline & & S3b1 & 10 & S3b1L & 2 & $\begin{array}{c}\text { Baqar drain (15 } \\
\text { years old ) }\end{array}$ & 0.7 \\
\hline & left & $\mathrm{S} 3 \mathrm{~h} 2$ & 27 & S3b2U & 0.5 & & 085 \\
\hline & & NJo & 21 & $\mathrm{~S} 32 \mathrm{~b} 2 \mathrm{~L}$ & 1.5 & moor & 0.05 \\
\hline & & $\mathrm{S} 3 \mathrm{~b}_{3}+2$ & 14 & S3b3U & 0.5 & & 1 \\
\hline & & S505 & 44 & S3b3L & 1.5 & moor & 1 \\
\hline & & Sub1 1 & 35 & S4b1U & 0.5 & Fill from Sarhan & 1 \\
\hline & & STOI & J & S4b1L & 3 & drain $(5$ years ago $)$ & 1 \\
\hline & & S4b? & 70 & $\mathrm{~S} 4 \mathrm{~b} 2 \mathrm{U}$ & 1 & & 15 \\
\hline$S 4$ & right & $\mathrm{N}+02$ & 10 & $\mathrm{~S} 4 \mathrm{~b} 2 \mathrm{~L}$ & 3.5 & moor & $1 . J$ \\
\hline & & & & S4b3U & 1.5 & Cultivated land & \\
\hline & & S4b3 & 106.5 & S4b3L & 3.5 & $\begin{array}{l}\text { using El-salam } \\
\text { canal water } \\
\end{array}$ & 2.3 \\
\hline & & $\mathrm{S} 5 \mathrm{~b} 1$ & 35 & S5b1U & 1 & Cultivated lands & 35 \\
\hline & & & & $\mathrm{S} 5 \mathrm{~b} 1 \mathrm{~L}$ & 4 & Baqar drain water & \\
\hline S5 & left & $\mathrm{c} 5 \mathrm{l} 9 \mathrm{P}$ & 70 & S5b2U & 1 & land adiicent to & \\
\hline & & SJ02 & 12 & $\mathrm{~S} 5 \mathrm{~b} 2 \mathrm{~L}$ & 3 & old fish farm & 2.5 \\
\hline & & & & S5b3U & 0.5 & New Fish & \\
\hline & & S5b3 & 120 & S5b3L & 3 & $\begin{array}{c}\operatorname{farm}(\text { two years } \\
\text { old ) }\end{array}$ & 0.7 \\
\hline S6 & right & S6b1 & 35 & S6b1U & 0.5 & $\begin{array}{c}\text { Fill from Bahr El- } \\
\text { Baqar drain (20 } \\
\text { years old) }\end{array}$ & 0.7 \\
\hline
\end{tabular}




\begin{tabular}{|c|c|c|c|c|c|c|c|}
\hline & & & & S6b1L & 2 & & \\
\hline & & \multirow{2}{*}{ S6b2 } & \multirow{2}{*}{67} & S6b2U & 0.5 & & \multirow{2}{*}{3.6} \\
\hline & & & & S6b2L & 3.75 & moor & \\
\hline & & \multirow[b]{2}{*}{ S6b3 } & \multirow[b]{2}{*}{114} & S6b3U & 0.5 & \multirow{2}{*}{$\begin{array}{c}\text { Cultivated land } \\
\text { using Bahr El- } \\
\text { Baqar drain }\end{array}$} & \multirow[b]{2}{*}{1.75} \\
\hline & & & & S6b3L & 2.5 & & \\
\hline \multirow{6}{*}{ S7 } & \multirow{6}{*}{ left } & \multirow{2}{*}{ S7b1 } & \multirow{2}{*}{35} & 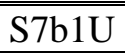 & 1 & \multirow[b]{2}{*}{ moor } & \multirow{2}{*}{1.5} \\
\hline & & & & S7b1L & 3 & & \\
\hline & & \multirow{2}{*}{ S7b2 } & \multirow{2}{*}{63} & S7b2U & 0.8 & \multirow[b]{2}{*}{ moor } & \multirow{2}{*}{1} \\
\hline & & & & S7b2L & 2 & & \\
\hline & & \multirow{2}{*}{ S7b3 } & \multirow{2}{*}{73} & S7b3U & 0.5 & \multirow{2}{*}{$\begin{array}{c}\text { land adjacent to } \\
\text { old fish farm }\end{array}$} & \multirow{2}{*}{0.7} \\
\hline & & & & S7b3L & 2 & & \\
\hline \multirow{6}{*}{ S8 } & \multirow{6}{*}{ left } & \multirow[b]{2}{*}{ S8b1 } & \multirow[b]{2}{*}{40} & 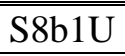 & 1 & \multirow{2}{*}{$\begin{array}{c}\text { Fill from Bahr El- } \\
\text { Baqar drain (15 } \\
\text { years old) }\end{array}$} & \multirow[b]{2}{*}{2.25} \\
\hline & & & & S8b1L & 2.75 & & \\
\hline & & \multirow[b]{2}{*}{$\mathrm{S} 8 \mathrm{~b} 2$} & \multirow[b]{2}{*}{80} & S8b2U & 1 & \multirow{2}{*}{$\begin{array}{c}\text { Fill from Bahr El- } \\
\text { Baqar drain (15 } \\
\text { years old) }\end{array}$} & \multirow[b]{2}{*}{2.75} \\
\hline & & & & S8b2L & 3 & & \\
\hline & & \multirow[b]{2}{*}{ S8b3 } & \multirow[b]{2}{*}{115} & S8b3U & 1 & \multirow{2}{*}{$\begin{array}{c}\text { Fill from Bahr El- } \\
\text { Baqar drain( } 20 \\
\text { years old })\end{array}$} & \multirow[b]{2}{*}{1.9} \\
\hline & & & & S8b3L & 2.2 & & \\
\hline
\end{tabular}

\section{RESULTS AND DISCUSSION}

\subsection{Water Samples from the drain}

Table (2) shows the concentrations of heavy metals for water samples taken from Bahr El- Baqar drain at the same study area one year before the study was conducted (Hamed et al 2011)[11]. The results reflect the size of pollution of the drain water along the whole year.

Table (2) The values of heavy metals in drain water for one year. (Hamed et al 2011)

\begin{tabular}{|c|c|c|c|c|c|c|c|c|}
\hline \multicolumn{3}{|c|}{ sites } & $\mathrm{Cu}$ & $\mathrm{Pb}$ & $\mathrm{Zn}$ & $\mathrm{Cd}$ & $\mathrm{Mn}$ & Mean of EC \\
\hline \multirow{16}{*}{ 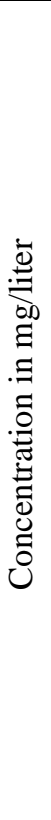 } & \multirow{4}{*}{ 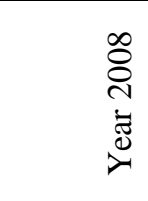 } & Sep. & 0.151 & 0.749 & 0.139 & 0.069 & 2.573 & \\
\hline & & Oct & 0.022 & 0.235 & 0.549 & 0.061 & 3.935 & \\
\hline & & Nov & 0.204 & 0.273 & 2.066 & 0.017 & 0.084 & \\
\hline & & Dec & 0.245 & 0.195 & 1.438 & 0.062 & 0.065 & 3.31 \\
\hline & \multirow{9}{*}{ 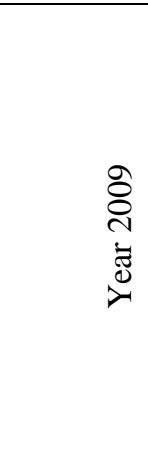 } & Jan & 0.062 & 0.088 & 0.431 & 0.101 & 0.281 & 4.2 \\
\hline & & Feb & 0.005 & 0.030 & 0.333 & 0.199 & 0.56 & 4.57 \\
\hline & & Mar & 0.045 & 0.287 & 0.688 & 0.032 & 0.278 & 4.24 \\
\hline & & Apr & 0.106 & 0.041 & 0.031 & 0.128 & 0.519 & 3.54 \\
\hline & & Jul & 0.083 & 0.033 & 0.095 & 0.001 & 0.064 & 4.53 \\
\hline & & Aug & 0.014 & 0.053 & 0.199 & 0.025 & 0.010 & 5.33 \\
\hline & & Sep & 0.012 & 0.009 & 0.024 & 0.021 & 0.011 & 4.04 \\
\hline & & Oct & 0.008 & 0.031 & 0.028 & 0.016 & 0.125 & 4.26 \\
\hline & & Nov & 0.011 & 0.066 & 0.051 & 0.016 & 0.816 & 4.25 \\
\hline & \multicolumn{2}{|c|}{ Mean } & 0.074462 & 0.160769 & 0.467077 & 0.057538 & 0.717 & 4.227 \\
\hline & \multicolumn{2}{|c|}{ FAO (irrigational water) } & 0.02 & 5 & 2 & 0.01 & 0.2 & \\
\hline & \multicolumn{2}{|c|}{ Who (drinking water) } & 3 & 0.05 & 5 & 0.005 & 0.05 & \\
\hline
\end{tabular}




\subsection{Comparison due to land use}

The objective of this section is to compare between different land uses with different water quality used. The comparison will be between old fish farms, new fish farms, lands adjacent to old fish farms, agricultural lands using polluted water from the drain, agricultural lands using fresh water from El-Salam canal, fill resulted from the excavation of the drain sides and bottom and finally natural lands (moor).

Fig (3) shows the difference between the concentrations of heavy metals in samples of top soil as a result of different land uses. The results showed that the old fish farms that used Bahr El-Baqar drain water have the highest percentage of heavy metals. the second highest rate exists in the agricultural land irrigated with polluted water from Bahr ElBaqar drain for long time. the third highest concentration of heavy metals is in the land adjacent to the fish farm that uses Bahr El-Baqar drain water. It indicates that the fish farms using polluted water significantly affect the neighboring land.

Next is land exposed to fill which exists only in top soil. In this case the concentration of heavy metals depends mainly on the age of the fill and its original location. There are two types of fill, that comes from polluted Bahr El-Baqar drain and fill comes from the agricultural minor drain (Sarhan drain). For fill from Bahr El-Baqar drain, the concentration is decreased with the increase of the fill age. The lowest concentration is for the fill 20-25 years age. It could be attributed to the increase in pollution of the drain bottom soil by time. The reason could be the increase in population and the increase in industry spread in the recent decades which cause increase in untreated waste water and industrial disposal spilled into the drain. In spit of the new fill comes from the relatively less polluted drain, Sarhan drain, it has a high concentration ratio of heavy metals. It is known that Sarhan drain receives drainage water from fish farms and agricultural

lands using polluted water from Bahr El-Baqar drain for irrigation and raising fish.

Next are the new fish farms that used Bahr El-Baqar drain water, and finally, the lowest heavy metal concentrations were found in both of the agricultural land using fresh water from El-Salam Canal and the natural lands (moor lands).

Fig (4) shows the difference between the concentrations of heavy metals in samples of lower soil as a result of different land uses. Nearly the same results as in top soil were obtained except for that the land adjacent to the fish farms which used Bahr El-Baqar drain water has the highest percentage of heavy metals. This is a good proof that the fish farms using polluted water significantly affect the neighboring land especially in lower soil layers. The old fish farms that used Bahr El-Baqar drain water have the second highest rate in the concentrations of heavy metals. The third highest concentration of heavy metals is the agricultural land irrigated with water from Bahr El-Baqar drain for a long time, next is the new fish farms that used Bahr El-Baqar drain water, next is the moor lands, and finally the agricultural land using fresh water from El-Salam Canal.

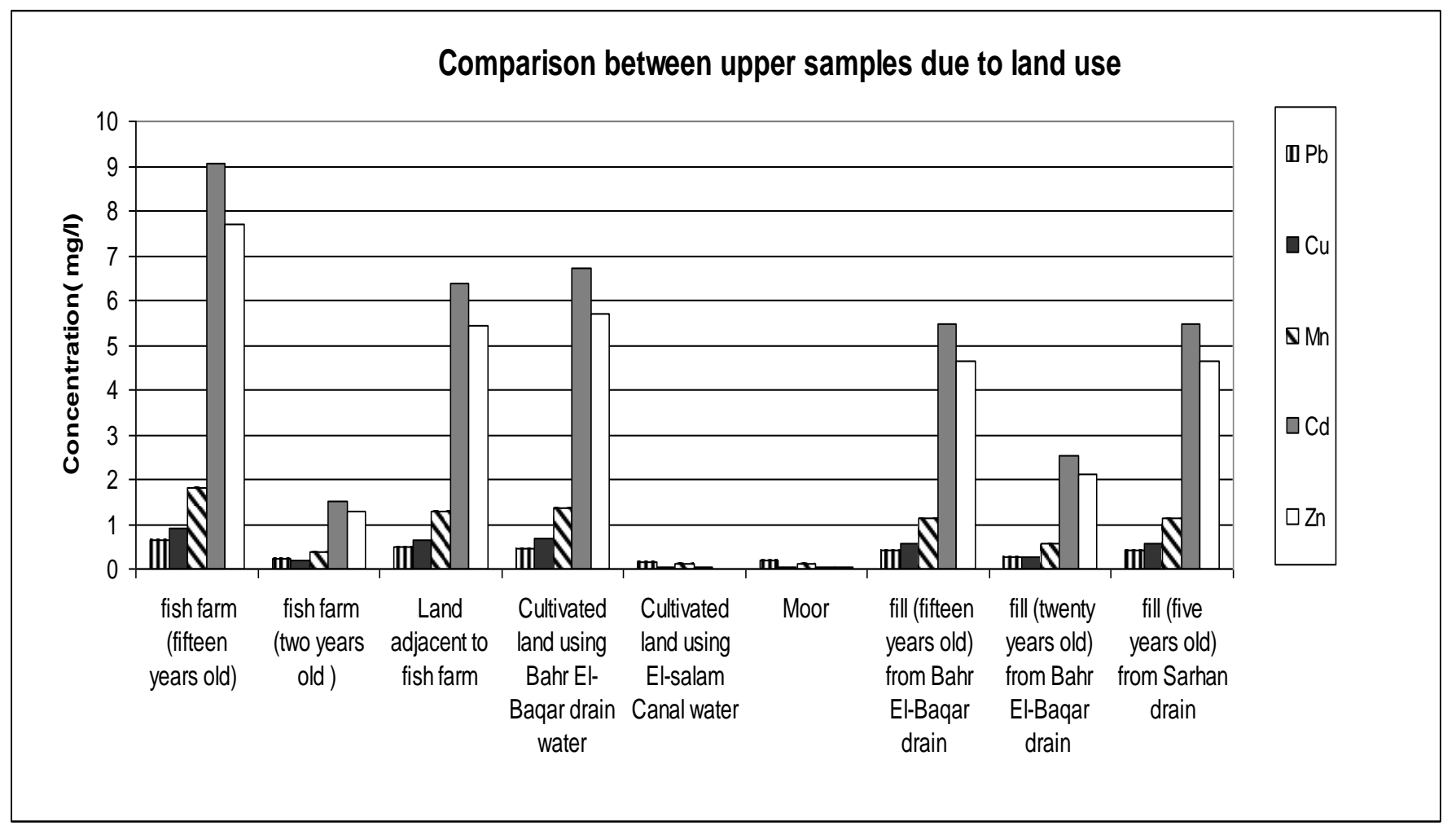

Fig (3) Mean heavy metals concentrations in upper soil samples for different land uses 


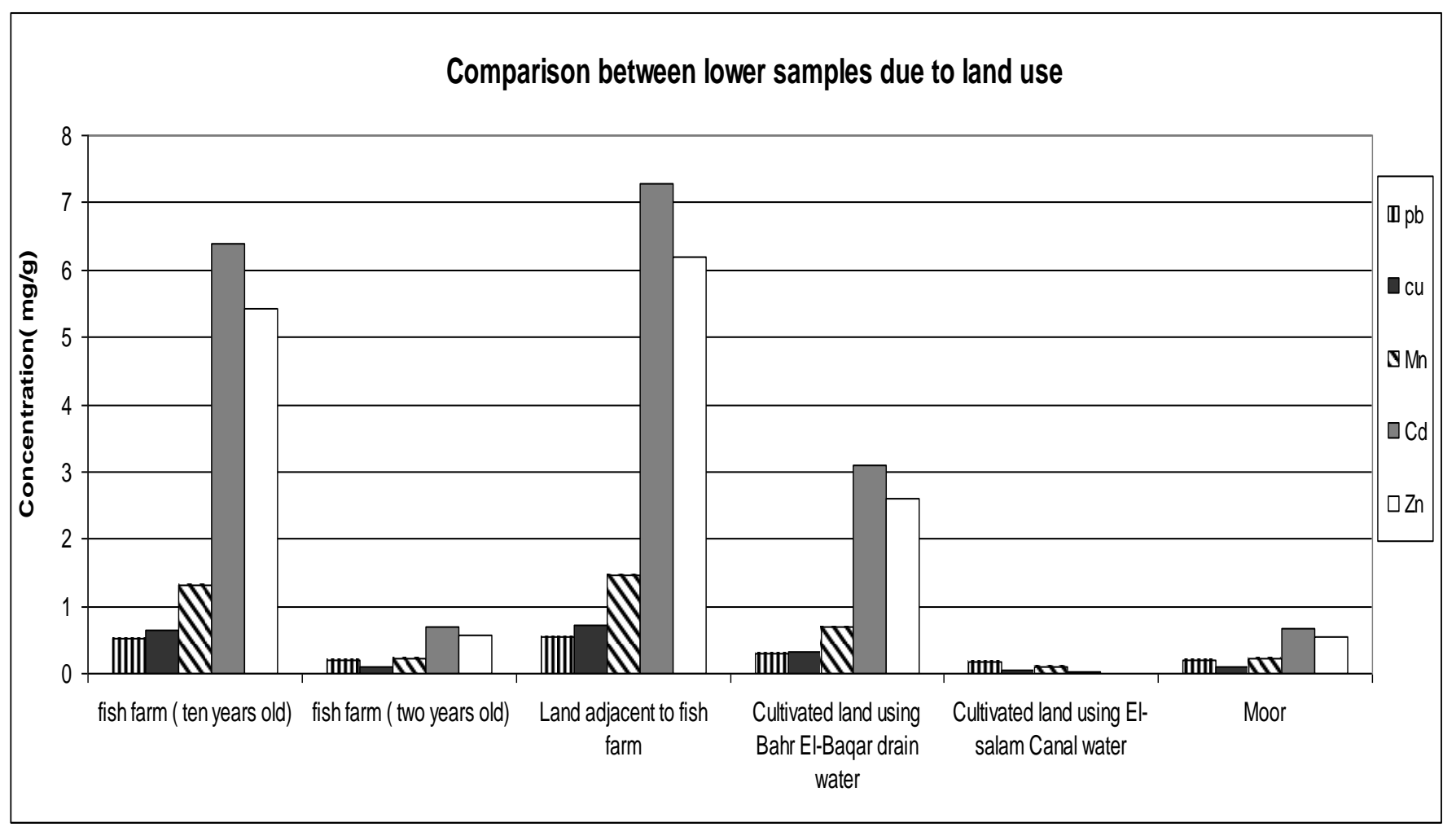

Fig (4) Mean heavy metals concentrations in lower soil samples for different land uses.

\subsection{Comparison due to location from Bahr El-Baqar drain}

In the current section, effect of seepage from the polluted drain to the adjacent lands will be investigated. Boreholes were dug in different distances and locations in lands with different land uses. The distances from the drain were kept nearly constants for different sections. Here, the effect of minor drain (Sarhan drain) parallel to Bahr El-Baqar drain and at $100 \mathrm{~m}$ far will be investigated. There is a question that needs to be answered," will the minor drain work as a defend barrier for seepage from the polluted drain to the lands located on the minor drain side?". For the coming section, only the data for the lower soil layer will be used in order to investigate the seepage from the drain.

Fig (5) shows heavy metals concentrations of boreholes in section (1). It shows concentrations in boreholes S1b1, S1b2 and S1b3 located in old fish farms, land adjacent to old fish farms and new fish farms respectively. It is clear from the figure that the seepage factor from the main drain is not dominating here. The highest heavy metal concentrations are found in bore hole S1b2 (land adjacent to old fish farm) not in S1b1 the closest borehole to the main drain. The effect of the minor drain (Sarhan drain) is not clear here since borehole S1b2 has a high ratio of heavy metals concentration. It is probably due to the influence of pump station near the section. It seems that the type of land use is the dominating factor for the pollution concentration in this section. It is clear also from S1b3 that all heavy metals exist160 $\mathrm{m}$ far from the drain although their concentrations are small compared with that in the drain water itself.

Fig (6) shows mean heavy metals concentrations of boreholes in section (2). It shows mean concentrations in boreholes S2b1, S2b2 and S2b3 located in old fish farms for the first two boreholes and fill from Sarhan drain for the third one. The highest heavy metal concentrations are found in borehole S2b2. Also, in this section it is clear that the seepage factor from the main drain is not dominating. The values of concentrations in old fish farm (10 years old $) 65 \mathrm{~m}$ far from the drain are higher than that the corresponding values in old fish farms $32.5 \mathrm{~m}$ away. The pollution in fill from Sarhan drain (5 years old) is less than that in old fish farms. It is probably due to the high pollution accumulation in old fish farms and the fill location near Sarhan drain

Fig (7) shows heavy metals concentrations in section (3). It shows concentrations in boreholes

S3b1, S3b2 and S3b3 located in fill from Bahr El-Baqar drain for the first borehole and moor land for the second and the third ones. The dominating factor here is the land use factor. The higher value of concentration exists in second borehole. The ratio of concentration in this section is small compared with other sections. It is probably due to moor lands (natural land) which contain less amount of pollution and the low effect of drain seepage. In fill borehole, the effect of fill is small since the soil sample was taken in $2 \mathrm{~m}$ depth. 
Fig (8) shows heavy metals concentrations in section (4). It shows concentrations in boreholes $\mathrm{S} 4 \mathrm{~b} 1, \mathrm{~S} 4 \mathrm{~b} 2$ and $\mathrm{S} 4 \mathrm{~b} 3$ located in fill from Sarhan drain (5 years ago ), moor land and agricultural lands using water from El-Salam canal respectively. The ratio of concentration in this section is small compared with other sections. The seepage factor here also is not dominating. The less concentration is found in agricultural lands using water from El-Salam canal. The location of Sarhan drain adjacent to the agricultural lands could be another factor contributing for lower pollution concentration in its soil.

Fig (9) shows heavy metals concentrations in section (5). It shows concentrations in boreholes S5b1, S5b2 and S5b3 located in cultivated lands using Bahr El-baqar drain water, land adjacent to old fish farm and New Fish farm (two years old) respectively. The higher concentrations of heavy metals are located in both of cultivated land with Bahr El-Baqar water and land adjacent to fish farms. These results reflect the bad effect of using polluted water for irrigation and the effect of fish farms on the adjacent lands. The relatively less concentration is located in new fish farms. However, only two years of fish farming using polluted water has raised the pollution concentration many times (see Fig (3) moor land and new fish farms)

Fig (10) shows heavy metals concentrations in section (6). It shows concentrations in boreholes S6b1, S6b2 and S6b3 located in Fill from Bahr El-Baqar drain (20 years old), moor lands and cultivated land using Bahr El-Baqar drain respectively. Soil sample was taken at $2 \mathrm{~m}$ depth in fill borehole. Consequently, the effect of fill is small. The ratios of concentration in moor land are nearly the same as that for old fill from Bahr El- Baqar drain. The unexpected results here are the lower ratio of concentration for cultivated land using Bahr El-Baqar drain although the soil sample was taken from the root zone area. It is probably due to the effect of Sarhan drain adjacent to the lands. However, the ratio of concentrations are still relatively high compared with land using fresh water for irrigation. Again, seepage is not a dominating factor here.

Fig (11) shows heavy metals concentrations in section (7). It shows concentrations in boreholes S7b1, S7b2 and S7b3 located in moor lands for the first two boreholes and in land adjacent to old fish farms for the third one. The effect of old fish farm on the lands nearby is quite clear here. The difference in heavy metals concentrations between land adjacent to fish farms and moor land is quite high. It reflects the damaging effect of fish farms not only on its own soil but also on the soil nearby. It is probably due to the high polluted water level in fish farms which infiltrate to the adjacent lower level lands.

Fig (12) shows heavy metals concentrations in section (8). It shows concentrations in boreholes S8b1, S8b2 and S8b3 located in fill from Bahr El-Baqar drain for 15, 15 and 20 years old respectively. Unlike other sections, seepage factor could be effective here. Another possible reason is the existence of some fill traces in deep layers.

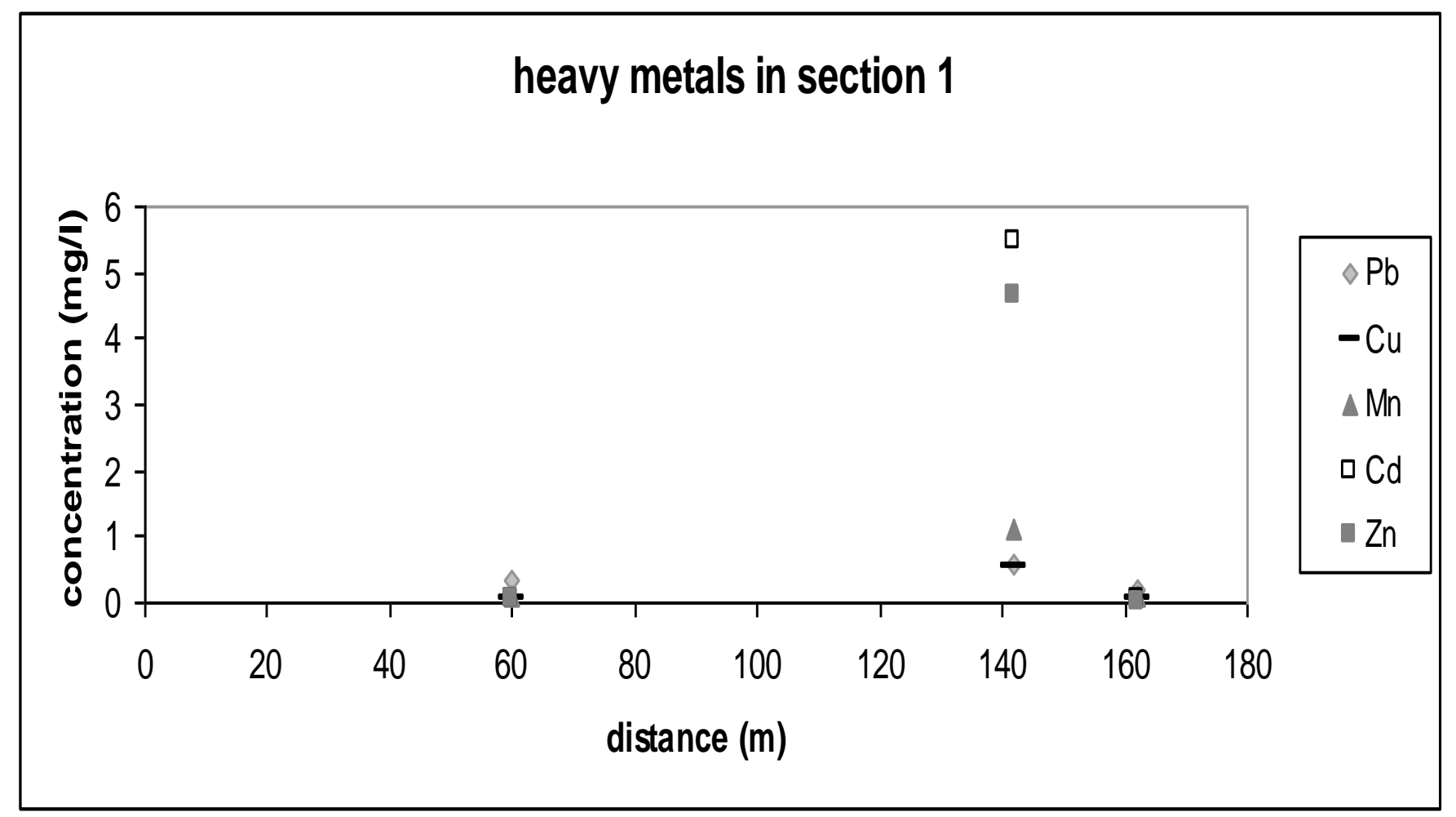

Fig (5) Heavy metals concentrations in section (1) 


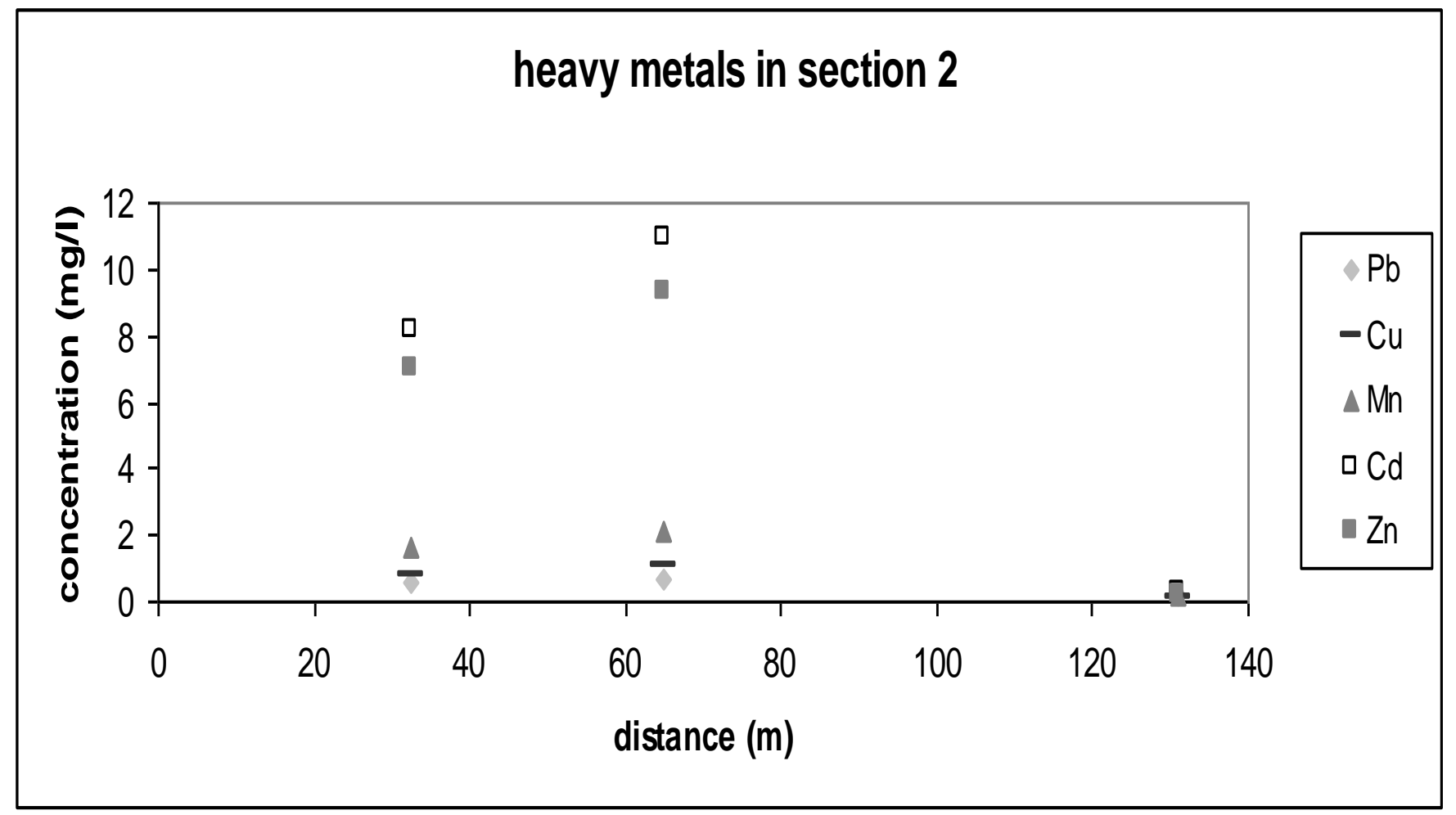

Fig (6) Heavy metals concentrations in section (2)

\section{heavy metals in section 3}

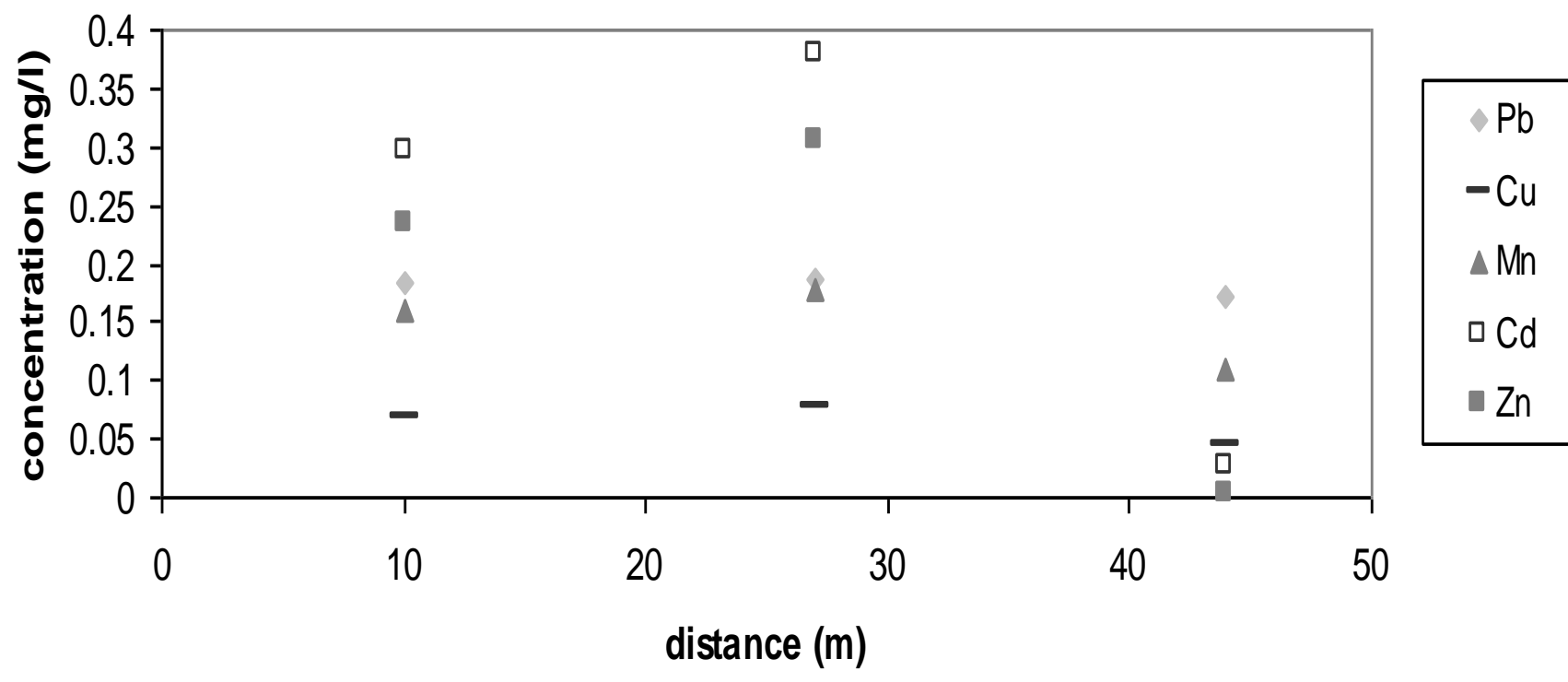

Fig (7) Heavy metals concentrations in section (3) 


\section{heavy metals in section 4}

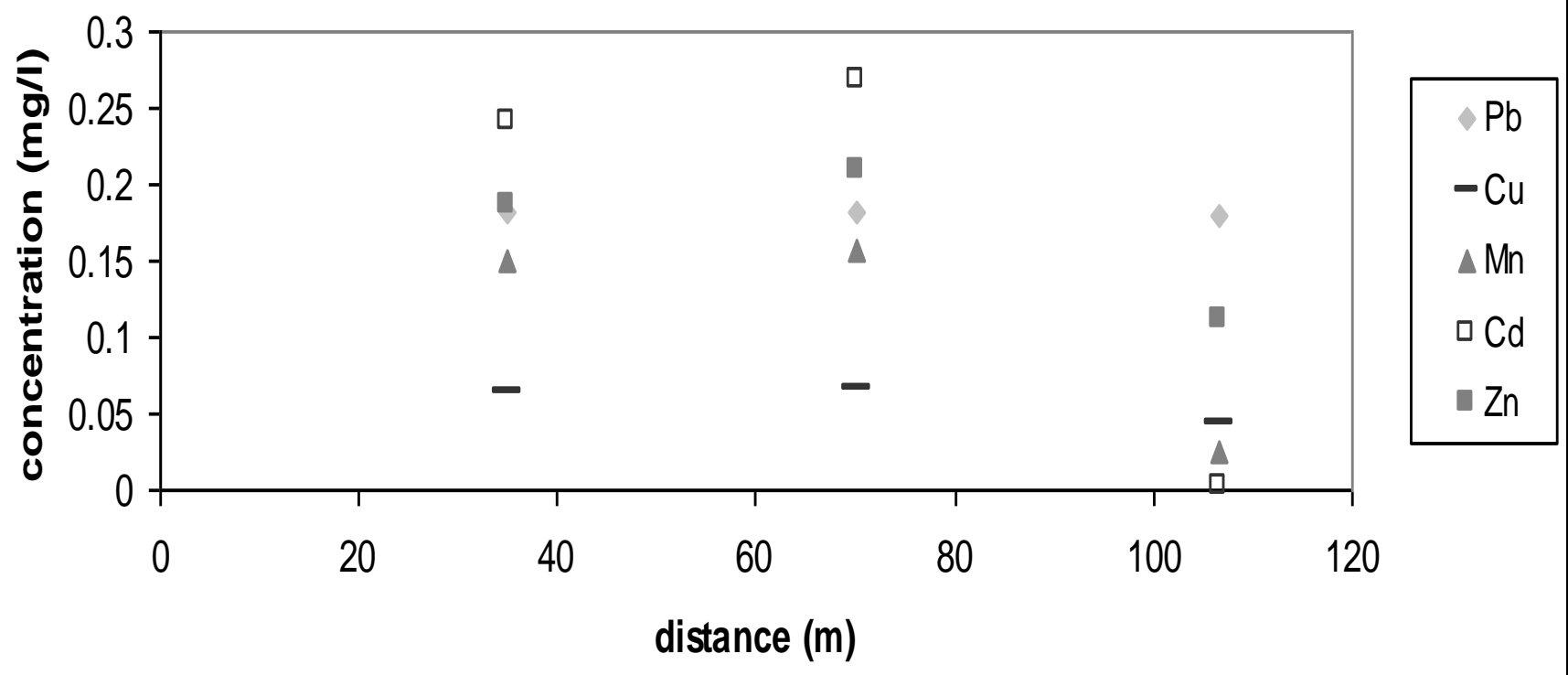

Fig (8) Heavy metals concentrations in section (4).

\section{heavy metals in section 5}

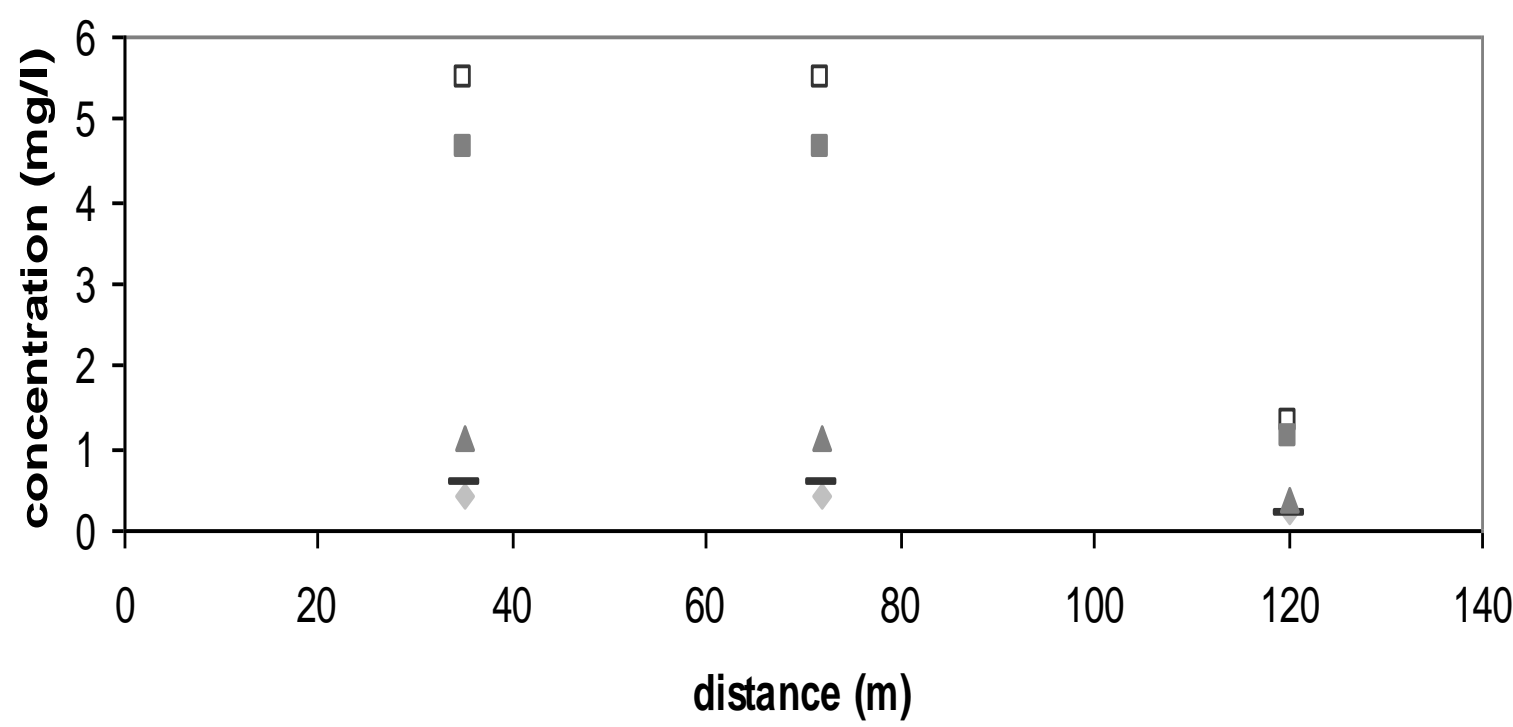

Fig (9) Heavy metals concentrations in section (5) 


\section{heavy metals in section 6}

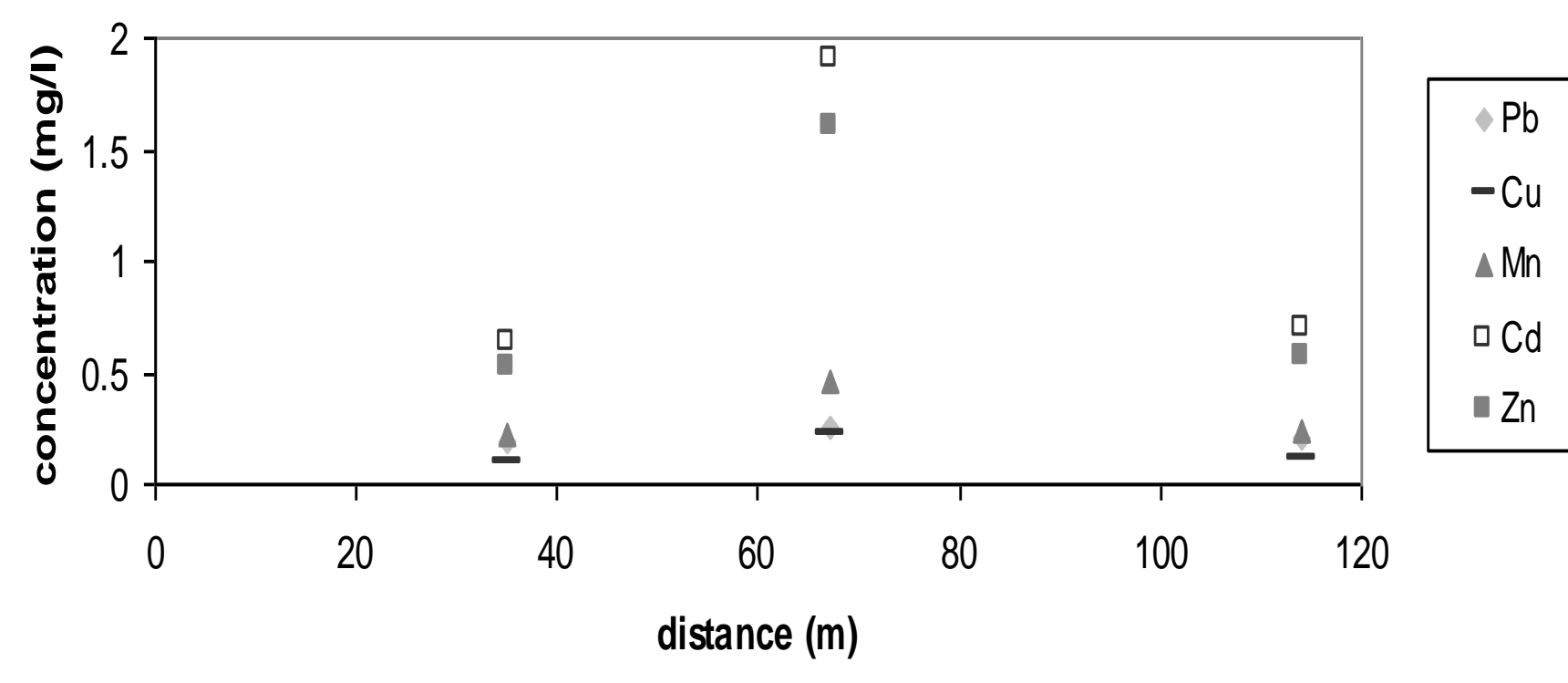

Fig (10) Heavy metals concentrations in section (6)

\section{heavy metals in section 7}

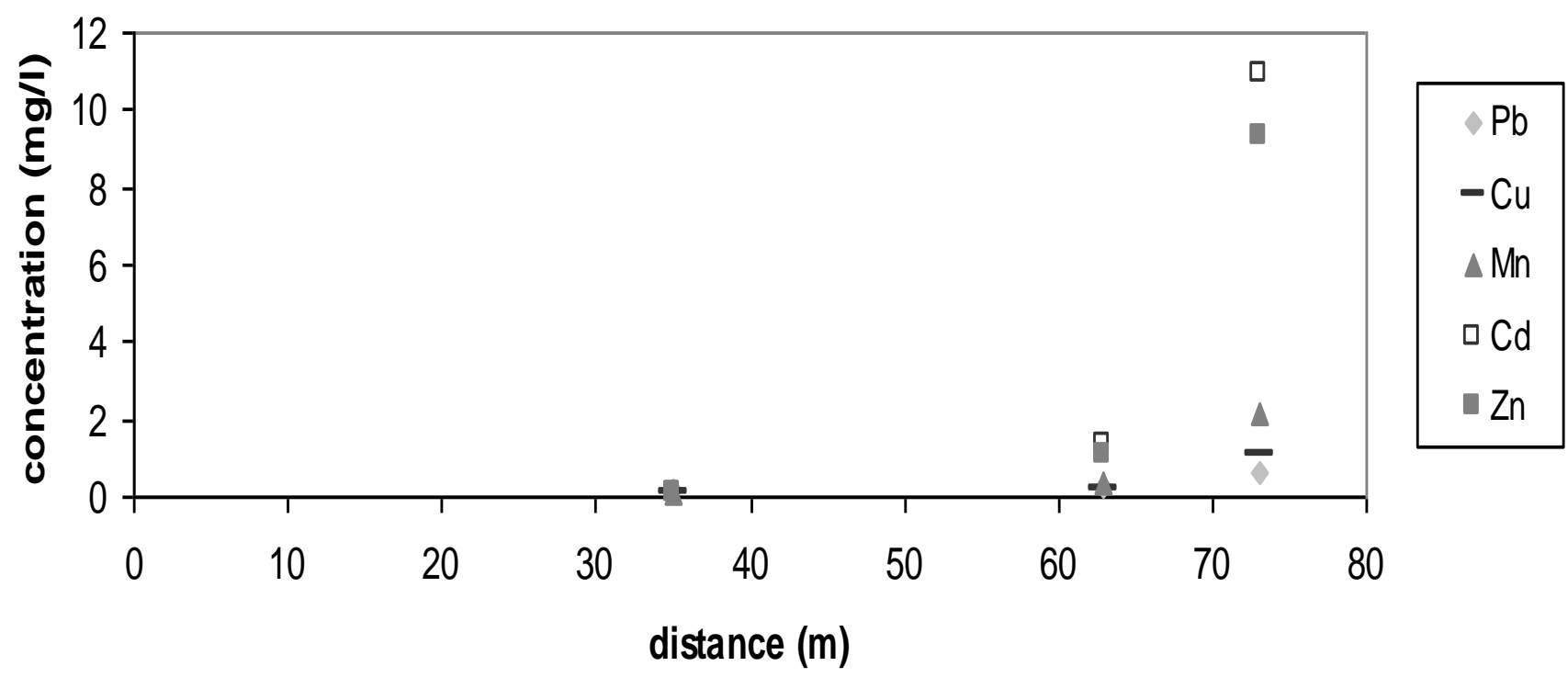

Fig (11) Heavy metals concentrations in section (7) 


\section{heavy metals in section 8}

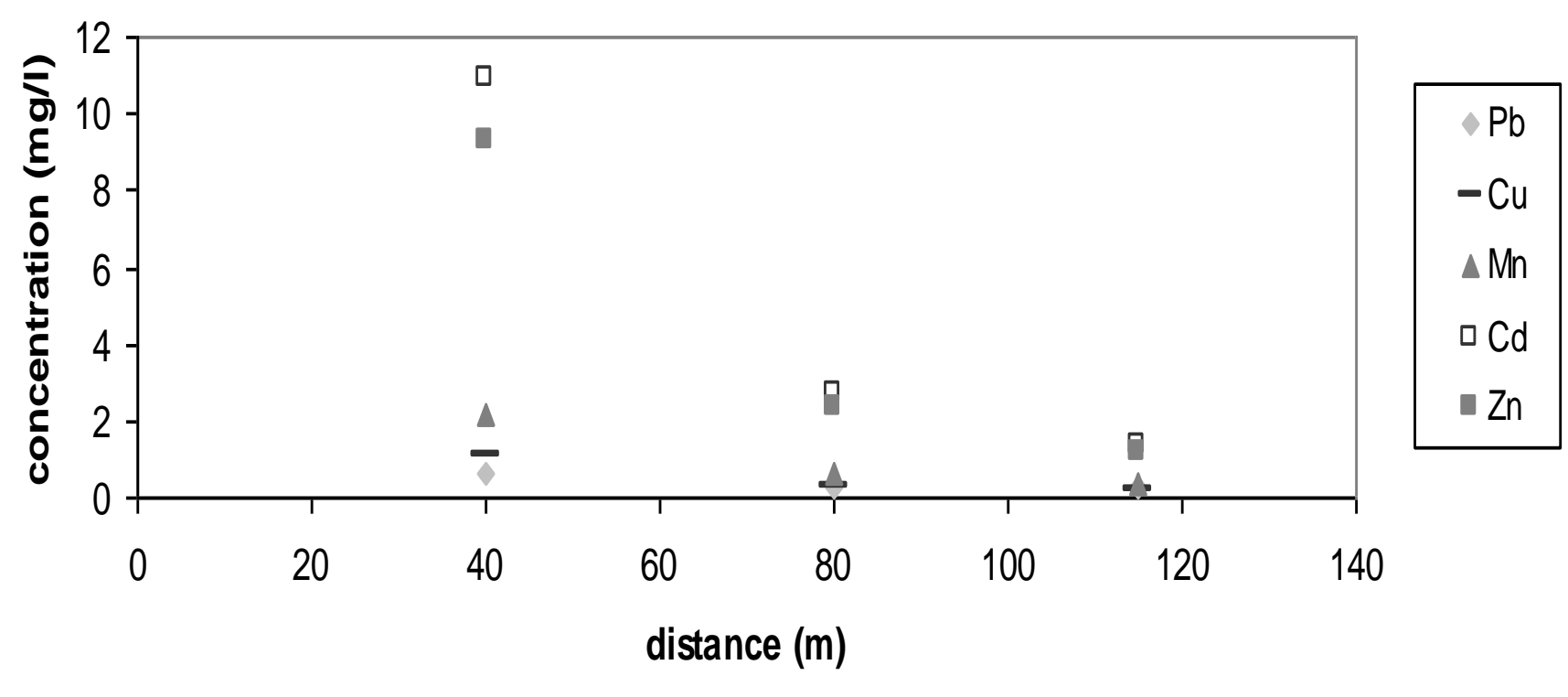

Fig (12) Heavy metals concentrations in section (8).

\section{SUMMARY AND CONCLUSIONS}

An integrated environmental assessment has been conducted in area located within the service area of the most polluted drain in Egypt (Bahr el Baqar drain). Total of 24 boreholes in 8 different sections on both sides of the drain have been dug in order to collect soil samples for depths ranging from 1 to $4 \mathrm{~m}$. Samples were sent to the laboratory in order to measure the concentrations of five heavy metals ( $\mathrm{Pb}, \mathrm{Zn}, \mathrm{Cd}, \mathrm{Cu}$ and $\mathrm{Mn})$. Boreholes were excavated in different land uses and in different spaces from the polluted drain. The effects of different land uses and locations from the polluted drain have been investigated.

The study showed that the most polluted areas are the old fish farms (10 years old) using polluted water from the drain for raising fish and the land adjacent to it. It reflects the harmful effect of using polluted water for long time for raising fish not only on farms soil itself but also on the soil adjacent to the fish farms. Consequently, the pollution will reach fish coming from these farms and transferred to human affecting their health. Moreover, even in new fish farms with only less than two years old, the increase in heavy metals concentrations in soil is quite high during short period of time.

The second higher ratio of pollution concentration is found in agricultural lands using polluted water from the drain in irrigation. This is a good proof for the bad effect of such kind of water on soil and hence in plants since the digging depth is within the root zone (1-3). This conclusion will stand against those people supporting the use of polluted drain water for irrigation.

Fill from both of Bahr El-Baqar drain and from agricultural drain (Sarhan drain) comes after as a third higher ratio of pollution. The quality of older fill from the polluted drain is better than the recent one. It is probably due to the increase in concentration of pollution by time in drain bottom soil. The difference in concentration is too high

in a relatively short period of time. This reflects the rapid deterioration of the environmental situation for Bahr El Baqar drain by time. Since fish farms and agricultural lands using polluted water are using the minor drain (Sarhan drain) for drainage, the fill coming from this drain contains high ratio of heavy metals concentration.

For agricultural lands which have used polluted water for irrigation for long time (20 years) and changed to use fresh water for relatively less period of time (5years), the improvement of its soil quality is quite clear. The decrease in heavy metals due to using good quality of water is rather high. It will give an optimistic view for obtaining a clue for pollution in the area. Furthermore, the existence of minor drain parallel to the major polluted drain in relatively small distance $(90-100 \mathrm{~m})$ contributes for reducing pollution for lands located after the minor drain in most cases.

Finally, the study revealed that the overall environmental situation at the area on both sides of the drain is quite dangerous. Five dangerous heavy metals with different concentrations have been found in each soil sample either on surface or deep on ground. This pollution hazardous level has its bad effect on both of fauna and flora at the area. 


\section{ACKNOWLEDGMENTS}

The field work was financially supported by the Swedish Research Council (SIDA) through a cooperation project between Suez Canal University (Egypt) and Lund University (Sweden) under the title: "Sustainable use of Cairo waste water; environmental effects of the Bahr El- Baqar Drain"

\section{REFERENCES}

[1] Abdel-Shafy, H. I., \& Aly, R. O. (2002). Water issue in Egypt: Resources, pollution and protection endeavors. CEJOEM, 8(1), 3-21.

[2] Ali, O. M.; El-Sikhry, E. M., and El-Farghal, W. M. (1993). Effect of prolonged use of Bahr El Baqar drain water for irrigation on the total heavy metals content of South Port Said soils. In: Proc. 1st Conf. Egypt. Hung. Env. Egypt, pp. 53-57.

[3] Abdel-Azeem, A. M; Abdel-Moneim, T. S.; Ibrahim, M. E.; Hassan, M. A. A. and Saleh, M. Y. (2007). Effects of Long-Term Heavy Metal Contamination on Diversity of Terricolous Fungi and Nematodes in Egypt - A Case Study. Water Air Soil Pollut. Journal, No. 186, pp.:233254.

[4] Rashed, I. G., \& Holmes, P. G. (1984). Chemical survey of Bahr El Bakar Drain system and its effects on Manzala Lake. In: Proceedings of the 2nd Egyptian Congress of Chemical Engineering, (pp. 1-10), Cairo, Egypt, March 18-20, 1984.
[5] Khalil, M. T. (1985). The effect of sewage and pollutional wastes upon Bahr El-Baqar Drain and the southern area of Lake Manzala, Egypt. Egyptian Journal of Wildlife and Natural Resources, 6, 162-171.

[6] Ezzat, A. I. (1989). Studies on phytoplankton in some polluted areas of Lake Manzala. Bulletin of the National Institute of Oceanography and Fisheries, ARE, 15(1), 1-19.

[7] Zaki, M. M. M. (1994). Microbiological and toxicological study of the environmental pollution of Lake Manzala (108 pp). MSc Thesis, Faculty of Science, Suez Canal University, Ismailia, Egypt

[8] Hamed, Y. 2008. Soil structure and salinity effects of fish farming as compared to traditional farming in northeastern Egypt. Land Use Policy Journal 25(3) pp 301-308, July 2008.

[9] Khalil, M. T., 1990. The physical and chemical environment of lake Manzala, Egypt. Hydrobiologia, 196:193-199.

[10] U. S. Environmental Protection Agency, USEPA (1986). Test methods for evaluating solid waste: physical/chemical methods. SW-846. Washington, D. C.: USEPA, Office of Solid Waste and Emergency Response.

[11] Hamed,Y., Shawky, T., Abd-Elrehim, M., ElKiki, M., Berndtsson, R. and Persson,K., 2011 Case Study: Investigation of different potential causes of pollution in Lake Manzala northeastern of Egypt. Article in Press. 